\title{
Soft Tissue Cephalometric Norms in Emirati Population: A Cross-Sectional Study
}

\author{
Huda Abutayyem (ID) \\ Amna Alshamsi ${ }^{2}$ \\ Mir Faeq Ali Quadri (iD ${ }^{3}$ \\ 'Department of Orthodontics, College of \\ Dental Sciences, Ras Al Khaimah \\ University, Ras Al Khaimah, United Arab \\ Emirates; ${ }^{2} \mathrm{Al}$ Qassimi Hospital, Ministry \\ of Health, Ras Al Khaimah, United Arab \\ Emirates; ${ }^{3}$ Department of Preventive \\ Dental Sciences, College of Dentistry, \\ Jazan University, Jazan City, Kingdom of \\ Saudi Arabia
}

Correspondence: Mir Faeq Ali Quadri Department of Preventive Dental Sciences, College of Dentistry, Jazan University, PO Box: II4, Jazan City, Kingdom of Saudi Arabia

Email dr.faeq.quadri@gmail.com
Introduction: The current study is the first to present the cephalometric norms in Emirati adults and aimed to investigate the differences in the angular and linear soft tissue cephalometric measures between male and female Emirati adults.

Methods: A group of 176 individuals (91 males and 85 females) with normal occlusion, proportional facial profiles were chosen, and lateral cephalograms were obtained. Standard values of 16 soft-tissue measurements were determined. Descriptive statistics were first carried out for each parameter. The Student's $t$-test was then performed to determine significant differences between male and female measurement means. Significant differences were determined at the $95 \%$ probability level.

Results: Soft tissue measurements showed that men had a greater soft tissue profile and $\mathrm{H}$-angle than women. A significant difference between the genders was observed for all linear soft tissue measurements except for the lower lip to E-plane, N'-Sn' and Sn'-Stomion/Sn-Me ratio measurements. The lengths and thicknesses of the upper and lower lips independently, protrusion of both upper and lower lips, Sn'-Me' (mm) and N'-Sn'/Sn'-Me' (\%) were found to be significantly different $(\mathrm{p}<0.001)$ and so were the upper lip to E-plane $(\mathrm{mm})$ and the soft tissue thickness of the chin measurements $(\mathrm{p}<0.05)$. Except for upper and lower lip protrusion dimensions and the N'Sn'/Sn'-Me' (\%), men presented with greater linear measurements.

Conclusion: The differences in soft-tissue cephalometric norms between men and women were established, suggesting that the orthodontist must individualize therapy using local norms as the reference.

Keywords: linear and angular measures, cephalometry, cephalometric measures, Emirates, Arab, orthodontic treatment

\section{Introduction}

Facial attractiveness is an inadequately defined perception, difficult to enumerate and linked to cultural preferences. Structural and other aspects of human facial appearance such as facial harmony, synchronization, and balance or equilibrium are best determined by the facial skeleton and its overlying soft tissue framework. ${ }^{1}$ In orthodontic treatment, harmonious facial esthetics and functional occlusion have long been recognized as two of the most important goals. Broadbent ${ }^{2}$ and Hofrath ${ }^{3}$ from the United States and Germany, respectively, were the first to present cephalometry in 1931, and since then, it has become one of the most reliable and reproducible diagnostic modalities in orthodontic practice. ${ }^{4}$ Standardized cephalometric analysis is used to obtain realistic guiding principles in orthodontic diagnosis and therapeutic scheduling, in addition to the evaluation of the patients' skeletal, dental and soft tissue patterns linked to their ethnic groups. 5,6 
Orthodontists need to become more aware of cephalometric norms of each ethnic group before starting with any type of orthodontic treatment, as it has been reported that norms specific to one group cannot always be applied to another group. Therefore, many research studies have been carried out to set up standardized cephalometric values for patients belonging to different ethnicities including but not limited to the Caucasians, European-Americans, ${ }^{6,7}$ AfricanAmericans, ${ }^{8,9}$ Mexican \& Puerto-Rican Americans, ${ }^{10,11}$ the Japanese, ${ }^{12,13}$ the Chinese, ${ }^{14}$ the Turkish ${ }^{15,16}$ and the Indians. ${ }^{17}$

Bishara et $\mathrm{al}^{18}$ reported that most Egyptian adolescent measurements were similar to North American norms, while Sarhan et $\mathrm{al}^{19}{ }^{19}$ Hassan et $\mathrm{al}^{20}$ and AlJasser et $\mathrm{al}^{21}$ reported that Saudis preferred greater proclination and protrusion of incisors in contrast to a group of North Americans and Caucasians, respectively. In addition, Sarhan and Hassan found Saudi adult men to exhibit more prognathism with bimaxillary skeletal retrusion when compared to Saudi adult women. ${ }^{19}$ Hamdan and Rock ${ }^{22}$ found a difference in the cephalometric norms between Jordanian and the Caucasians in relation to the Eastman standards, where Jordanian subjects were reported to be present with incisor protrusion.

When comparing soft tissue cephalometric norms of distinct ethnic groups, differences in clinical implication have been revealed, predominantly in size and position of the nose, prominence and curvature of the lips, thicknesses of soft tissues covering the chin and the length of the lips among other parameters. Using the Holdaway soft tissue analysis, Al-Gunaid et $\mathrm{al}^{23}$ and Mafi et al ${ }^{24}$ reported that most Yemeni and Iranian adult measurements were different from white norms, whereas Basciftci et $\mathrm{al}^{16}$ reported similar soft-tissue cephalometric norms between the Turkish and the white.

At present, a great number of young Emirati adults are seeking orthodontic treatment. Very few and inadequate research studies have been conducted focusing on soft tissue cephalometric norms in adults from the United Arab Emirates, necessitating the need to carry out precise and comprehensive research studies on these standards for the population in question. Therefore, the current study is the first to present the cephalometric norms in Emirati adults and to investigate if there are differences in the angular and linear soft tissue cephalometric measures between male and female Emirati adults.

\section{Materials and Methods}

\section{Ethical Considerations}

The research proposal was reviewed, and ethical approval was granted by the Al Qassimi Hospital Research Ethics Committee, Ministry of Health, the United Arab Emirates (UAE). Written and signed consent was obtained from the study participants before carrying out clinical examinations and data collections. All participants were informed about the purpose of the study, in accordance with the Declaration of Helsinki.

\section{Sample Selection Criteria}

Inclusion criteria comprise UAE nationals, age range between 19 and 25 years, having balanced soft-tissue profiles, having Class I molar relationships, presence of permanent dentition only and no history of any previous trauma, any orthodontic or prosthodontic treatment, any maxillofacial or plastic surgery, any congenital facial anomalies, and any systemic diseases affecting dentofacial growth.

Those subjects with facial asymmetry or deformity, presence of deciduous/retained teeth, severe crowding, previous or current orthodontic treatment, evidence of previous trauma or surgery, obvious periodontal disease, or presence of any other pathological conditions were excluded.

\section{Sampling Procedure and Sample Size}

The study subjects were recruited using a convenience sampling technique. Patients visiting the Department of Orthodontics, Sharjah Dental Centre, Ministry of Health, Sharjah, UAE, during the study period of January to November 2019 were subjected to the selection criteria. A sample of 176 adult Emiratis (91 males and 85 females) from health centers, high schools and colleges from different areas of the UAE fulfilled the selection criteria and agreed to participate in the study.

The power of the study was calculated using the OpenEpi software to check if the sample size of 176 adult Emiratis (91 males and 85 females) was adequate. With $5 \%$ precision and $30 \%$ prevalence in the exposed group, and a prevalence coverage ratio of 3 , the power was estimated at $91.58 \%$, which is satisfactory for presenting a conclusive finding.

\section{Study Variables}

Soft Tissue Cephalometric Study

Lateral cephalometric radiographs were taken for each subject according to the Broadbent method using the 
Table I Soft Tissue Cephalometric Measurements Used in the Study

\begin{tabular}{|c|c|}
\hline \multicolumn{2}{|l|}{ Angular Measurements } \\
\hline Facial convexity (G'SnPog'o) & $\begin{array}{l}\text { The angle between soft tissue glabella, subnasale and the soft tissue pogonion. Measures the convexity of the } \\
\text { soft tissue profile. }\end{array}$ \\
\hline $\mathrm{H}$-angle & $\begin{array}{l}\text { The angle between soft tissue labralesuperious, soft tissue nasion and Pog'. Measures the prominence of the } \\
\text { upper lip in relation to N'pog' line. }\end{array}$ \\
\hline Z-angle & $\begin{array}{l}\text { The angle between soft tissue labralesuperious, pogonion (profile line) and Frankfort horizontal plane. } \\
\text { Measures the amount of lip protrusion. }\end{array}$ \\
\hline Nasolabial angle & The angle between a line tangent to the base of the nose and a line tangent to the upper lip. \\
\hline Soft tissue profile (N'SnPog' $\left.{ }^{\circ}\right)$ & Measures the degree of soft tissue convexity regardless of the nose prominence. \\
\hline Soft tissue convexity $\left(\mathrm{N}^{\prime} \mathrm{PnPog}{ }^{\circ}\right)$ & Measures the degree of soft tissue convexity including the nose. \\
\hline Nasal prominence $\left(\mathrm{PnN}^{\prime} \mathrm{Sn}^{\circ}\right)$ & Measures the degree of nasal prominence. \\
\hline \multicolumn{2}{|l|}{ Linear Measurements } \\
\hline Length of upper lip (Sn-Sto) & Length of the upper lip measured between subnasale and stomionsuperius. \\
\hline Length of lower lip (Sto-Sm) & Length of the lower lip measured between stomion and mentolabial sulcus. \\
\hline Ls-E line & $\begin{array}{l}\text { The horizontal distance between labralesuperious and esthetic line. It measures the relative protrusion of the } \\
\text { upper lip to the esthetic line. }\end{array}$ \\
\hline Li-E line & $\begin{array}{l}\text { The horizontal distance between labraleinferius and esthetic line. It measures the relative protrusion of the } \\
\text { lower lip to the esthetic line. }\end{array}$ \\
\hline $\begin{array}{l}\text { Thickness of the red portion of } \\
\text { the upper lip: }\end{array}$ & $\begin{array}{l}\text { Measured from the labial surface of the prominent upper incisor to the most anterior point of the upper lip } \\
\text { parallel to the FH plane. }\end{array}$ \\
\hline $\begin{array}{l}\text { Thickness of the red portion of } \\
\text { the lower lip: }\end{array}$ & $\begin{array}{l}\text { Measured from the labial surface of the prominent lower incisor to the most anterior point of the lower lip } \\
\text { parallel to the FH plane. }\end{array}$ \\
\hline $\begin{array}{l}\text { Thickness of the soft tissue chin } \\
\text { (Pog-Pog') }\end{array}$ & The horizontal distance between the hard and soft tissue pogonion. \\
\hline Upper lip protrusion (Ls-SnPog') & $\begin{array}{l}\text { The horizontal distance between the most anterior point of the upper lip and subnasale soft tissue pogonion } \\
\text { line. It measures the relative protrusion or retrusion of the upper lip to theSnPog' line. }\end{array}$ \\
\hline Lower lip protrusion (Li-SnPog') & $\begin{array}{l}\text { The horizontal distance between the most anterior point of the lower lip and subnasale soft tissue pogonion } \\
\text { line. It measures the relative protrusion or retrusion of the lower lip to theSnPog' line. }\end{array}$ \\
\hline \multicolumn{2}{|l|}{ Proportional Analysis } \\
\hline N'-Sn & Nasal third, the vertical distance between the soft tissue nasion and the subnasale points. \\
\hline Sn-Me' & Gnathic third, the vertical distance between the subnasale and the soft tissue menton points. \\
\hline N'-Sn: Sn-Me' (\%) & The ratio between nasal third and gnathic third. \\
\hline Sn-Sto/Sn-Me' (\%) & The ratio between the vertical distance of the subnasale and stomion to gnathic third. \\
\hline
\end{tabular}

Planmeca proline XC system at the Ibn Sina Medical Centre, UAE. For consistency purposes, all the radiographs were taken by the same person, with the same machine, and employing the same method. Dolphin imaging system software package version 10.5 was utilized to perform the digital cephalometric analysis comprising 7 angular and 9 linear measurements (Table 1).

All the measurements were performed by one orthodontist (HM) and reviewed twice by two different investigators, and no discrepancies were reported. The analysis 
Table 2 Descriptive Statistics of Angular and Linear Soft Tissue Measurements in Male and Female Study Participants

\begin{tabular}{|c|c|c|c|c|c|c|c|c|c|c|}
\hline \multirow[t]{2}{*}{ Variables } & \multicolumn{5}{|c|}{ Males $(\mathbf{N}=91)$} & \multicolumn{5}{|c|}{ Females $(\mathbf{N}=\mathbf{8 5})$} \\
\hline & Mean & SD & SE & Min & Max & Mean & SD & SE & Min & Max \\
\hline \multicolumn{11}{|c|}{ Angular soft tissue measurements } \\
\hline Facial convexity G’ Sn Pog' $\left(^{\circ}\right)$ & 163.33 & 5.76 & 0.6 & 157.2 & 169.2 & 165.29 & 4.51 & 0.49 & 161.2 & 169.32 \\
\hline $\mathrm{H}$-angle & 14.56 & 4.46 & 0.47 & 10.2 & 19.1 & 12.99 & 3.84 & 0.42 & 9.6 & 16.2 \\
\hline Z-angle & 74.08 & 9 & 0.94 & 68.1 & 84.7 & 78 & 7.89 & 0.86 & 71.2 & 85.93 \\
\hline Nasolabial angle & 117.62 & 10.48 & 0.1 & 106.3 & 128.2 & 120.13 & 10.72 & 0.16 & 110.9 & 130.87 \\
\hline Soft tissue profile angle $\mathrm{N}^{\prime} \mathrm{SnPog}\left(^{\prime}\left({ }^{\circ}\right)\right.$ & $|56.9|$ & 6.92 & 0.73 & 149.2 & 162.8 & 133.8 & 5.51 & 0.02 & 128.6 & 138.5 \\
\hline Soft tissue convexity N'PnPog' $\left({ }^{\circ}\right)$ & 127.48 & 4.78 & 0.5 & 122.93 & 132.3 & 136.85 & 8.03 & 0.96 & 128.3 & 145.1 \\
\hline Noseprominence Pn N'Sn ( $\left.{ }^{\circ}\right)$ & 20 & 2.22 & 0.23 & 17.9 & 22.34 & 20.73 & 6.29 & 0.68 & 14.8 & 27.2 \\
\hline \multicolumn{11}{|c|}{ Linear soft tissue measurements } \\
\hline Upper lip length $(\mathrm{mm})$ & 27.08 & 1.53 & 0.1 & 25.1 & 28.7 & 16.8 & 2.35 & 0.34 & 14.9 & 18.7 \\
\hline Lower lip length $(\mathrm{mm})$ & 25 & 2.49 & 0.15 & 22 & 28 & 21 & 5.86 & 0.8 & 16 & 27 \\
\hline Upper lip to E-plane (mm) & -5.88 & 3.56 & 0.37 & -2.8 & -6.1 & -1.8 & 4.03 & 0.52 & -3.2 & 2.2 \\
\hline Lower lip to E-plane (mm) & -2.23 & 4.41 & 0.46 & 1.2 & -2.7 & -1.32 & 4.42 & 0.48 & -5.1 & 2.1 \\
\hline Thickness of red portion of upper lip (mm) & I5.II & 5.68 & 0.6 & 10.4 & 20.81 & 11.83 & 4.84 & 0.53 & 7.6 & 16.7 \\
\hline Thickness of red portion of lower lip & 12.21 & 3.85 & 0.4 & 8.72 & 16.42 & 8.49 & 5.1 & 0.55 & 3.2 & 13.54 \\
\hline Thickness of soft tissue chin (Pog-Pog') (mm) & 14.5 & 7.12 & 0.75 & 7.36 & 21.72 & 11.48 & 7.24 & 0.79 & 4.5 & 18.64 \\
\hline Upper lip protrusion (Ls-SnPog') (mm) & 3.47 & 2.2 & 0.34 & 1.4 & 5.8 & 12.01 & 2.66 & 0.13 & 10.8 & 14.73 \\
\hline Lower lip protrusion (Li-SnPog') (mm) & 3.72 & 2.68 & 0.39 & 1.2 & 6.4 & 11.75 & 2.16 & 0.08 & 9.54 & 13.9 \\
\hline $\mathrm{N}^{\prime}-\mathrm{Sn}$ (mm) & 71.98 & 3.62 & 0.48 & 68.3 & 75.5 & 70.07 & 2.33 & 0.31 & 68.21 & 72.41 \\
\hline Sn'-Me' (mm) & 93.2 & 3.28 & 0.28 & 89.6 & 96.73 & 70.33 & 4.45 & 0.65 & 65.2 & 74.61 \\
\hline N'-Sn': Sn'-Me' (\%) & 77.62 & 8.73 & 0.92 & 68.9 & 86.32 & 84.3 & 11.33 & 0.23 & 75.02 & 95.52 \\
\hline Sn-Stomion/Sn-Me (\%) & 33.22 & 5.14 & 0.54 & 27.8 & 38.40 & 32.72 & 2.53 & 0.27 & 29.8 & 35.19 \\
\hline
\end{tabular}

was repeated on forty randomly selected cephalometric radiographs after three weeks, and the results were statistically compared using the Dahlberg formula. The intraoperator error ranged from $0.35^{\circ}$ to $0.44^{\circ}$ for angular measurements and $0.15^{\circ}$ to $0.48^{\circ}$ for linear measurements. No differences were determined, and intra-operator reliability was deemed satisfactory.

\section{Statistical Analysis}

Descriptive statistics were first carried out for each parameter. The Student's $t$-test was then performed to determine significant differences between male and female measurement means. Significant differences were determined at the $95 \%$ probability level. All statistical analyses were carried out using the Statistical Package for the Social Sciences (SPSS; IBM; USA) version 24.0.

\section{Results}

The lateral cephalometric radiographs of the study participants with Class I malocclusion were analyzed to establish a normative database. Descriptive statistics (mean, standard deviation and standard error) of the angular and linear soft tissue measurements in the male and female study participants are shown in Table 2. The significance of the difference between the male and female samples was tested with the Student's $t$-test (Table 3 ). Statistical analysis showed that there were significant differences with all angular soft tissue measurements, by sex except in the nasolabial angle and nose prominence dimensions.

Soft tissue measurements showed that men had a greater soft tissue profile and $\mathrm{H}$-angle than women. The significance of the difference for linear soft tissue measurements between the male and female samples was tested with the Student's $t$-test (Table 3). A significant difference by sex was observed for all linear soft tissue measurements except for the lower lip to E-plane, N'-Sn' and Sn'-Stomion/Sn-Me ratio measurements. The lengths and thicknesses of the upper and lower lips independently, protrusion of both upper and lower lips, Sn'-Me' (mm) and N'-Sn'/Sn'-Me' (\%) were noted to be statistically significantly different $(\mathrm{p}<0.001)$ and so were the upper lip to E-plane ( $\mathrm{mm})$ and the soft tissue thickness of the chin measurements $(\mathrm{p}<0.05)$, except for the upper and lower lip protrusion dimensions and the N'-Sn'/Sn'-Me' (\%). 
Table 3 Comparison of Soft Tissue Cephalometric Angular and Linear Measurements Between Males and Females

\begin{tabular}{|c|c|c|c|c|c|c|}
\hline \multirow[t]{2}{*}{ Variables } & \multicolumn{2}{|c|}{ Male $(\mathbf{N}=91)$} & \multicolumn{2}{|c|}{ Female $(\mathbf{N}=\mathbf{8 5})$} & \multirow[t]{2}{*}{$\mathbf{t}$} & \multirow[t]{2}{*}{$\mathbf{P}$} \\
\hline & Mean & SD & Mean & SD & & \\
\hline \multicolumn{7}{|c|}{ Angular soft tissue measurements } \\
\hline Facial convexity G' Sn Pog' $\left(^{\circ}\right)$ & 163.33 & 5.76 & 165.29 & 4.51 & -2.52 & $<0.05^{*}$ \\
\hline $\mathrm{H}$-angle & 14.56 & 4.46 & 12.99 & 3.84 & 2.51 & $<0.05^{*}$ \\
\hline Z-angle & 74.08 & 8.99 & 78.0 & 7.89 & -3.06 & $<0.05^{*}$ \\
\hline Nasolabial angle & 117.62 & 10.48 & 120.13 & 10.72 & -1.57 & $>0.05$ \\
\hline Soft tissue profile angle N'SnPog'( $\left.{ }^{\circ}\right)$ & 156.91 & 6.92 & 133.80 & 5.51 & 3.81 & $<0.001 * *$ \\
\hline Soft tissue convexity N'PnPog' $\left({ }^{\circ}\right)$ & 127.48 & 4.78 & 136.85 & 8.03 & -4.64 & $<0.001 * *$ \\
\hline Noseprominence Pn N’Sn $\left({ }^{\circ}\right)$ & 20.0 & 2.22 & 20.73 & 6.30 & -1.01 & $>0.05$ \\
\hline \multicolumn{7}{|c|}{ Linear soft tissue measurements } \\
\hline Upper lip length (mm) & 27.08 & 1.53 & 16.80 & 2.35 & 5.92 & $<0.001^{* *}$ \\
\hline Lower lip length (mm) & 25.0 & 2.49 & 21.0 & 5.86 & 6.56 & $<0.001 * *$ \\
\hline Upper lip to E-plane (mm) & -5.88 & 3.56 & -1.80 & 4.03 & -2.60 & $<0.05^{*}$ \\
\hline Lower lip to E-plane (mm) & -2.23 & 4.41 & -1.32 & 4.42 & -1.36 & $>0.05$ \\
\hline Thickness of red portion of upper lip (mm) & 15.11 & 5.68 & 11.84 & 4.84 & 4.11 & $<0.001 * *$ \\
\hline Thickness of red portion of lower lip & 12.20 & 3.85 & 8.49 & 5.10 & 5.43 & $<0.001 * *$ \\
\hline Thickness of soft tissue chin (Pog-Pog') (mm) & 14.50 & 7.12 & $\mathrm{II} .48$ & 7.24 & 2.79 & $<0.05^{*}$ \\
\hline Upper lip protrusion (Ls-SnPog') (mm) & 3.47 & 2.20 & 12.01 & 2.66 & -3.96 & $<0.001 * *$ \\
\hline Lower lip protrusion (Li-SnPog') (mm) & 3.72 & 2.68 & 11.75 & 2.16 & -3.80 & $<0.001^{* *}$ \\
\hline N'-Sn'(mm) & 71.98 & 3.62 & 70.07 & 2.33 & 0.56 & $>0.05$ \\
\hline Sn'-Me' (mm) & 93.20 & 3.28 & 70.33 & 4.45 & 5.42 & $<0.001 * *$ \\
\hline N'-Sn': Sn'-Me' (\%) & 77.62 & 8.73 & 84.30 & 11.33 & -4.36 & $<0.001 * *$ \\
\hline Sn-Stomion/Sn-Me (\%) & 33.22 & 5.14 & 32.72 & 2.54 & 0.80 & $>0.05$ \\
\hline
\end{tabular}

Notes: $\mathrm{P}=$ probability level. *Significant $(\mathrm{P}<0.05)$; **Highly significant $(\mathrm{P}<0.00 \mathrm{I})$.

\section{Discussion}

One need was to consider differences in the cephalometric norms between racial and ethnic groups of different populations. Therefore, norms of a definite population may not apply to other ethnic groups necessitating the conduct of studies specific to each ethnicity/group. ${ }^{25,26}$ Besides, with the increasing number of Emiratis seeking specialized treatment from orthodontists, maxillofacial surgeons, or plastic and reconstructive surgeons, it would be useful to settle on what constitutes a pleasing and esthetic face for this population. The present study aimed to develop cephalometric soft-tissue norms that can assist in orthodontic diagnosis and treatment schedules for young Emirati adult males and females. Facial harmony and esthetics are principally associated with racial preferences. The available norms pertinent to Caucasians/ Americans cannot be standardized and applied to other races unless personalized. Comparative research studies have been conducted for different races in various countries. For instance, in East Asia, craniofacial norms are characterized by oblong eyes and small nose, whilst these features may not be acknowledged as norms in other ethnic groups. ${ }^{25,26}$ Studies carried out on Egyptians, ${ }^{18}$ Yemenis $^{23}$ and Indians ${ }^{27}$ established greater facial convexity in these populations in comparison with the Caucasians. Normative data of normal samples of different ethnic groups is a helpful guide, and identifying the normal range of cephalometric values for a given population is necessary to diagnose abnormalities effortlessly. ${ }^{13}$

Our findings of soft tissue measurements showed noteworthy differences between the sexes; the mean soft tissue facial angle of men was superior to that of women, suggesting that women have more convex facial profiles. However, Legan and Burstone, ${ }^{28}$ Scheideman ${ }^{7}$ and others presented contrasting findings with no significant difference between the sexes. Stark and Epker defined the nasal profile parameters of American men and women on traced cephalograms to establish the normal value of nasal parameters. ${ }^{29}$ The nose prominence of women $(20.73-6.30 \mathrm{~mm})$ in this study was found to be higher than that of men (20$2.29 \mathrm{~mm}$ ). These findings are not in concurrence with those of Abdel Mageed et $\mathrm{al}^{30}$ and Mohamed et al. ${ }^{31}$ 
In our study, males had extra protrusive lips and chin when compared to females. It may be due to the thicker soft-tissue structures in males. This was assured by a $p$-value $<0.05$, increased G,Sn'Pog' as well as $\mathrm{H}$-angle and decreased $\mathrm{Z}$-angle in men. Similar results were reported by Kalha et $\mathrm{al}^{32}$ and Sachan et $\mathrm{al}^{33}$ in the south and north Indian ethnic populations, correspondingly. Using the E-plane as a reference, however, the lips appeared more retrusive in Emirati adult males owing more to the soft tissue chin protrusion rather than the actual procumbence of the lips. Upper and lower lip lengths were significantly higher in men attributing to a greater lower facial height. These findings align with those reported by Abdel Mageed et al, ${ }^{30}$ Mohamed et $\mathrm{al}^{31}$ and Scheideman et al. ${ }^{7}$

The differences in soft tissue parameters between different races highlight the importance of defining what is normal for a specific ethnic group. The differences further signify the need for developing distinct sets of values between the sexes. The main benefit of this study is giving standard lateral soft-tissue cephalometric measurements for Emirati adults of both genders helping in diagnosis and treatment planning for orthodontic and surgical decisions and improving post-treatment outcomes.

The above-mentioned differences between diverse races or ethnicities are accredited to genetics, epigenetic and residing in diverse geographical locations. The obtained data in this study emphasize the further need for defining groupspecific norms for each population/ethnic population to augment the achievement of orthodontic treatment and attain higher patient satisfaction. Further studies including more assessors of facial profile attractiveness and more subjects, in general, are desirable to explicate the topic.

\section{Conclusion}

The present study developed normative soft-tissue cephalometric data for the nationals of the United Arab Emirates, which will assist in diagnosis and management planning. From the findings of the present study, it has been concluded that females possess a more convex facial soft-tissue profile when compared to males, females have more nasal prominence in contrast to males, and males have thicker soft tissue structures than females. The present study is of the view that orthodontic treatment must be individualized with the help of local norms according to sex as the reference rather than using norms established for other ethnic groups.

\section{Data Sharing Statement}

The data is available with Huda Abutayyem and will be released on reasonable request.

\section{Author Contributions}

All authors made a significant contribution to the work reported, whether that is in the conception, study design, execution, acquisition of data, analysis and interpretation or in all these areas; took part in drafting, revising or critically reviewing the article; gave final approval of the version to be published; have agreed on the journal to which the article has been submitted; and agreed to be accountable for all aspects of the work.

\section{Funding}

No funding was received.

\section{Disclosure}

The authors declare no conflicts of interest for this work, financial or otherwise.

\section{References}

1. AlMansoub YAM, Jubari M, Li A, Jun L, Tang S. Patient's facial soft tissue changes following the orthodontics treatment. IOSR J Dent Med Sci. 2019;18:69-78.

2. Broadbent BH. A new X-ray technique and its application to orthodontia. Angle Orthod. 1931;1:45-66.

3. Hofrath H. Die bedeutung der roentgenfern der kieferanomalien. Fortschr Orthod. 1931;1:232-248.

4. Athanasiou A. Orthodontic Cephalometry. London: Mosby-Wolfe; 1997.

5. Bishara SE, Jacobsen JR, Hession TJ, Treder JE. Soft tissue profile changes from 5 to 45 years of age. Am J Orthod Dentofacial Orthop. 1998;114(6):698-706. doi:10.1016/S0889-5406(98)70203-3

6. Bishara SE, Fernandez AG. Cephalometric comparisons of the dentofacial relationships of two adolescent populations from Iowa and Northern Mexico. Am J Orthod. 1985;88(4):314-322. doi:10.1016/ 0002-9416(85)90131-9

7. Scheideman GB, Bell WH, Legan HL, Finn RA, Reisch JS. Cephalometric analysis of dento-facial normals. Am J Orthod. 1980;78(4):404-420. doi:10.1016/0002-9416(80)90021-4

8. Drummond RA. A determination of cephalometric norms for the Negro race. Am J Orthod. 1968;54(9):670-682. doi:10.1016/00029416(68)90018-3

9. Fonseca RJ, Klein WD. A cephalometric evaluation of American Negro women. Am J Orthod. 1978;73(2):152-160. doi:10.1016/ 0002-9416(78)90185-9

10. Swierenga D, Oesterle LG, Messersmith ML. Cephalometric values for adult Mexican Americans. Am J Orthod Dentofacial Orthop. 1994;106(2):146-155. doi:10.1016/S0889-5406(94)70032-X

11. Evanko AM, Freeman K, Cisneros GJ. Mesh diagram analysis: developing a norm for Puerto Rican Americans. Angle Orthod. 1997;67:381-388.

12. Miyajima K, McNamara JA Jr, Kimura T, Murata S, Iizuka T. Craniofacial structure of Japanese and European-American adults with normal occlusions and well-balanced faces. Am J Orthod Dentofacial Orthop. 1996;110(4):431-438. doi:10.1016/S08895406(96)70047-1

13. Alcalde RE, Jinno T, Pogrel MA, Matsumura T. Cephalometric norms in Japanese adults. J Oral Maxillofac Surg. 1998;56 (2):129-134. doi:10.1016/S0278-2391(98)90849-7 
14. Yen PKJ. The facial configuration in a sample of Chinese males Angle Orthod. 1973;43:301-304.

15. Erbay EF, Canikliog 'lu CM, Erbay SK. Soft tissue profile in Anatolian Turkish adults: part I. Evaluating of horizontal lip position using different soft tissue analyses. Am J Orthod Dentofacial Orthop. 2002;121(1):57-64. doi:10.1067/mod.2002.119780

16. Basciftci FA, Uysal T, Buyukerkmen A. Determination of Holdaway soft tissue norms in Anatolian Turkish adults. Am J Orthod Dentofacial Orthop. 2003;123(4):395-400. doi:10.1067/mod.2003.139

17. Nanda R, Nanda RS. Cephalometric study of the dentofacial complex of North Indians. Angle Orthod. 1969;39:22-28.

18. Bishara SE, Abdullah EM, Hoppens BJ. Cephalometric comparisons of dentofacial parameters between Egyptian and North American adolescents. Am J Orthod Dent Orthop. 1990;97(5):413-421. doi:10.1016/0889-5406(90)70113-Q

19. Sarhan OA, Nashashibi IA. A comparative study between two randomly selected samples from which to derive standards for craniofacial measurements. $J$ Oral Rehabil. 1988;15(3):251-255. doi:10.1111/j.1365-2842.1988.tb00154.x

20. Hassan AH. Cephalometric norms for the Saudi children living in the western region of Saudi Arabia: a research report. Head Face Med. 2005;24:1-5.

21. Al-Jasser NM. Cephalometric evaluation of craniofacial variation in normal Saudi population according to Steiner analysis. Saudi Med J. 2000;21:746-750.

22. Hamdan AM, Rock WP. Cephalometric norms in an Arabic population. $J$ Orthod. 2001;28(4):297-300. doi:10.1093/ortho/ 28.4.297

23. Al-Gunaid T, Yamada K, Yamaki M, Saito I. Soft tissue cephalometric norms in Yemeni men. Am J Orthod Dent Orthop. 2007;132: e7-14.
24. Mafi P, Ghazisaeidi MR, Mafi A. Ideal soft tissue facial profile in Iranian females. J Craniofac Surg. 2005;16(3):508-511. doi:10.1097/ 01.scs.0000171971.21808.d1

25. Azarbayejani S, Omrani A, Kalaantar- Motamedi A, Abdellahi M, Taalebi V, Teimoori F. Cephalometric norms for 6-17 year-old Iranians with normal occlusion and well-balanced faces. Dent Res J. 2014;11:327-335

26. Jacobson A, Jacobson R. Radiographic Cephalometry from Basic to 3-D Imaging. Quintessence Pub Co; 2006:205-216.

27. Jain P, Kalra JP. Soft tissue cephalometric norms for a North Indian population group using Legan and Burstone analysis. Int J Oral Maxillofac Surg. 2011;40(3):255-259. doi:10.1016/j.ijom.2010.09.011

28. Legan HL, Burstone CJ. Soft tissue cephalometric analysis for orthognathic surgery. J Oral Surg. 1980;38:744-751.

29. Stark A, Epker BN. Cephalometric analysis of profile nasal aesthetics. Part 1: methods and normative data. Int J Adult Orthodon Orthognath Surg. 1996;11:91-103.

30. Abdelmageed HA. A cephalometric study of soft tissue profile in relation to the hard tissue in a group of Egyptian adults. Egypt: Faculty of oral and dental medicine, Cairo University; 1989.

31. Mohammad AMQ. Lateral cephalometric norms for a sample of Jordanian adults. Egypt: Cairo University; 2003.

32. Kalha AS, Latif A, Govardhan SN. Soft-tissue cephalometric norms in a South Indian ethnic population. Am J Orthod Dentofacial Orthop. 2008;133(6):876-881. doi:10.1016/j.ajodo.2006.05.043

33. Sachan A, Srivastav A, Chaturvedi TP. Soft-tissue cephalometric norms in a north Indian ethnic population. J Orthod Sci. 2012;1 (4):92-97. doi:10.4103/2278-0203.105877
Journal of Multidisciplinary Healthcare

\section{Publish your work in this journal}

The Journal of Multidisciplinary Healthcare is an international, peerreviewed open-access journal that aims to represent and publish research in healthcare areas delivered by practitioners of different disciplines. This includes studies and reviews conducted by multidisciplinary teams as well as research which evaluates the results or conduct of such teams or healthcare processes in general. The journal covers a very wide range of areas and welcomes submissions from practitioners at all levels, from all over the world. The manuscript management system is completely online and includes a very quick and fair peer-review system. Visit http://www.dovepress.com/testimonials. php to read real quotes from published authors. 